\title{
野外観察力, 写真読解力及び地形図の読図力の発達と育成
}

\section{I.はじめに}

社会科の授業, 中でも地理的内容の授業に和け る写真や地図の利用や，野外観察の実施は，教育 効果を高めるのに役立っている。これらの観察力 や読み取り能力が学年とともに高まることについ ては, 先行研究もあるが, まだ, 不明確な面もあ って実際の授業にそれが必しも十分生かされてい るとはいえない。

学習指導要領は, ほぼ10年毎に改訂されてい る。それに伴って文部省ではその解説を含めて指 導書を発刊するのが常である。さらに，具体的な 指導資料を刊行する場合も多い。指導書や指導資 料には，これまでの研究成果に基づいた内容が盛 られているが，児童のレベルが不明確であったり 1), ややレベルが高かったり2)して，具体的に実 際の授業とは結びっきにくい面があった。社会科 に特ける観察力や読図力の育成は, 一層重視する 傾向にあり, 最近では, 具体的に子どものレベル を配慮してきてはいる ${ }^{34)}$ 。しかし，まだ，全体 としては授業に具体的に生かすことは難しいよう である。

観察力の発達については, 椙村大涁ら 8 名の共 同研究がある ${ }^{5)}$ 。ここでは, 野外観察, 写真観察 などを採り上げている。対象児童は, 各学年の成 績上位者を集め, 自由観察群, 指導観察群に分け て調査している。その結果, 素朴的直感観察一比 較観察一相関観察一総合観察と発達すること, 教 師の適切な指導が効果を上げることなどを報告し ている。近年, 地理教育の中に新しい地理学の考 え方を導入する試みがみられ, 発達心理学の成果 や方法も採り入れた研究が目立ってきている6)。 例兄ば, 寺本潔は ${ }^{7)}, \mathrm{S}$ 君の知覚環境の拡大, 深 化の事例を通して，子ぞもが身近な地域の像（イ メージ)を主体的に構成していくことを報告して
いる。また, 山口幸男, 黒崎至高は ${ }^{8)}$, 距離, 位 置，面積を採り上げ，例觉ば，距離については， 小学校 3 年生の上位者は距離認知の正確さがみら れ，4年生で更に確実になる，乙調査結果を報告 している。さらに, 岩本広美は9", R. ハートの 論文を抄訳し，その中でデータ分析のために空間 組織を 5 つの水準に分けていることを紹介してい る。すなわち，(1)，空間的まとまりがない，(2)連 結されている, (3)空間的に接近している, (4), 空 間的に順序づけられている，(5，位置づけがはっ きりしている，であるこれは一つの発達例とみて よからう。寺本潔は ${ }^{10)}$, これまでの研究成果をも とにして，子ぞもの手描き地図を通して子どもの 知覚空間の拡大や遊び行動の変容を分析し, その 発達についてまとめている。

中学校については, 地形図の読図について, 筆 者が調査したことがある11)。ここでは, 中学校 1 年生と 2 年生の読図力の差が大きく， 2 年生にな ると科学的な論理と多様な思考をしようとする傾 向が強いことがわかった。1 年生では, 上位生徒 が同様な傾向にあるが，中・下位生徒はその前段 階であった。また, 中学校入学後の「身近な地 域」の学習の前後で地形図の読図力がどのように 変化するか調査したことがある ${ }^{12)}$ 。学習前では, 一般的読図に㧧いて，記号のみで指摘する者と等 高線と関連させて説明しようとする者が注ぼ半々 であったが, 学習後では, 後者が $80 \%$ を超え, さ らに，幾つもの事象を関係づけて説明する者が出 たことがわかった。写真については, 渋沢文隆の 研究がある ${ }^{13)}$ 。生徒の写真資料の読み取り調査を し, その結果を基に写真資料の教材化の方向を論 じている。高水準の生徒を対象にしただけに，生 徒の読みとりや疑問は, 極めて多種多様でレベル も高い。とくに，写真の場所がどこかを知りたい という疑問が強いことは，興味のある点である。 
以上のような研究成果は, 新教科「生活科」を 指導する際の基礎的役割を果すと同時に，小学校 3 年生から始をる社会科教育, さらに, 中学校社 会科比ける地理教育との関連を図るとき，幾多 の示唆を与えるるのと思われる。しかし，これら の研究が統一されて系統化されないうらみもあ る。筆者の調査も 3 つの読みとり能力についてあ えて先行研究の中に位置づようとするものでは ない。方法としてあまりみられない面接法を用 い, 子ぞもの発達傾向を少しでも具体的に把握し て授業の際に役立てたいと考えた。

\section{II. 調查の方法}

1）使用した資料

フ3階建校舎の屋上からみた風景

1 熱带雨林気候 (マレーシア) の写真 (東京 書籍のカード式掛図・中学校用地理・世界)

ウ 2.5 万分の 1 地形図「東金」(団土地理院・ 昭55改測)

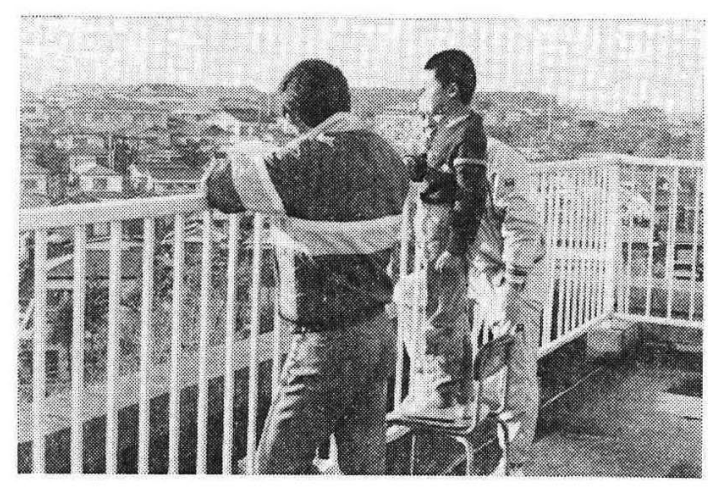

写真 1 ア. 屋上からの観察

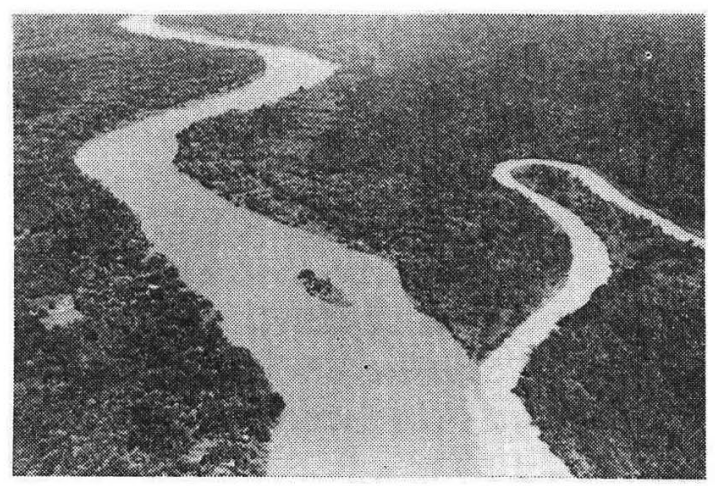

写真 2 1. ジャングル（実物はカラー写真）

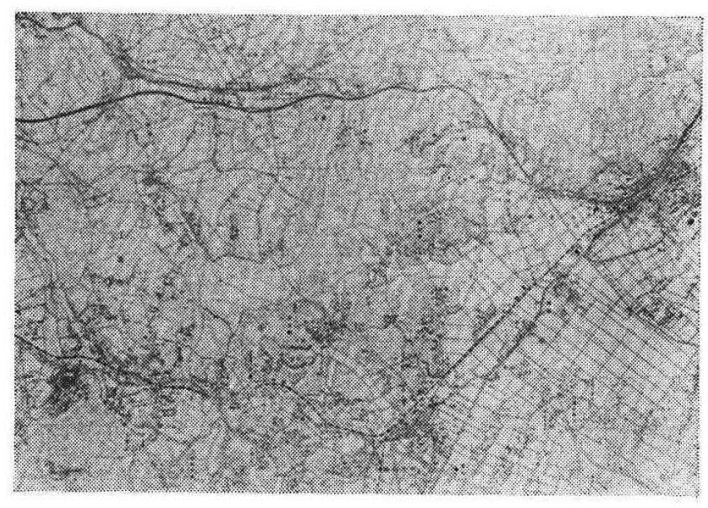

写真 3 ウ. 地形図 (東金)

\section{2) 対象児童}

千葉市立柏井小学校第 2 学年～第 6 学年児童 60 名 (昭和62年度在籍)

調査対象児童の選定にあたっては，第 2 学年〜 第 6 学年の各クラス担任に依頼した。クラス内に 適任者のいない場合には, 学年としての選定を依 頼した。選定にあたっては，次の基準によった。

A. クラスで社会科学習においてトップレベル にあり, 偏差值65以上

B. クラスで社会科学習において中のやや上に あり, 偏差値 $50 \sim 60$ 程度

C. クラスで社会科学習において下のやや上で あり, 偏差値 $35 \sim 45$ 程度

対象児童は下表の通りである。一部で偏差值が 基準通りにならなかったが，選定した担任は，学 習中の社会科の学力からみて妥当であるといって いる。

なお，対象児童のクラス担任は，社会科をとく に専門に研究している者は皆無である。このこと は，調查には好都合であった。

\section{3）調查の形態}

筆者の他に 3 名の教員が協力し， 2 名 1 組にな って, 屋上からの風景, 写真と地形図からの読み とりに分かれ，面接法によって調査した。調査は 1名が質問者, 他が記録者である。

\section{4）予備調查と共通理解}

本調査の前に予備調査を実施した。第 2 学年〜 第 6 学年から男女各 1 名（中の上）を選定し, 風 


\begin{tabular}{|c|c|c|c|c|c|c|c|c|c|c|c|}
\hline & & 表 1 & 調 & 査 & 対 & 象 & 児 & 童 & & & \\
\hline \multirow{2}{*}{ 学 年 } & 2 & 年 & 3 & 年 & 4 & 年 & 5 & 年 & 6 & 年 & 計 \\
\hline & 男 & 女 & 男 & 女 & 男 & 女 & 男 & 女 & 男 & 女 & \\
\hline A & $\begin{array}{l}67 \\
67\end{array}$ & $\begin{array}{l}62 \\
58\end{array}$ & $\begin{array}{l}73 \\
67\end{array}$ & $\begin{array}{l}69 \\
65\end{array}$ & $\begin{array}{l}68 \\
63\end{array}$ & $\begin{array}{l}80 \\
67\end{array}$ & $\begin{array}{l}70 \\
68\end{array}$ & $\begin{array}{l}65 \\
61\end{array}$ & $\begin{array}{l}75 \\
70\end{array}$ & $\begin{array}{l}70 \\
65\end{array}$ & $\begin{array}{l}\text { (人) } \\
20\end{array}$ \\
\hline B & $\begin{array}{l}55 \\
50\end{array}$ & $\begin{array}{l}56 \\
50\end{array}$ & $\begin{array}{l}60 \\
59\end{array}$ & $\begin{array}{l}58 \\
54\end{array}$ & $\begin{array}{l}59 \\
59\end{array}$ & $\begin{array}{l}60 \\
57\end{array}$ & $\begin{array}{l}58 \\
55\end{array}$ & $\begin{array}{l}58 \\
56\end{array}$ & $\begin{array}{l}60 \\
55\end{array}$ & $\begin{array}{l}57 \\
56\end{array}$ & 20 \\
\hline C & $\begin{array}{l}41 \\
39\end{array}$ & $\begin{array}{l}38 \\
38\end{array}$ & $\begin{array}{l}47 \\
43\end{array}$ & $\begin{array}{l}42 \\
40\end{array}$ & $\begin{array}{l}45 \\
44\end{array}$ & $\begin{array}{l}44 \\
44\end{array}$ & $\begin{array}{l}42 \\
42\end{array}$ & $\begin{array}{l}39 \\
39\end{array}$ & $\begin{array}{l}47 \\
35\end{array}$ & $\begin{array}{l}44 \\
42\end{array}$ & 20 \\
\hline 計 & 1 & & 12 & & 12 & & 1 & & 12 & & 60 \\
\hline
\end{tabular}

（数字は, 日文式知能偏差值）

景写真, 地形図，その他の地図などそれぞれ数種 を用いて実施した。その結果，上記の資料 3 点を 決定した。同時に，調查時の質問，記録，対象児 童への対応など，調查者 4 名の共通理解を図っ た。とくに，最初の質問「どんなことでもわかる ことをすべて答えなさい。質問があれば遠慮なく しなさい」以外は, 教師側からの質問はしないよ らにした。乙かし，何をいってよいかわからない 児童には，きっかけになる説明や質問を行った。

児童の解答について，その表現が稚拙な場合が あり, 調査者の判断に誤解を生じては困るので, 補助的質問をしたり，子ぞものつぶやきなどから 判断したりして，児童のいいたいことを把握した。

\section{5）調査期間之時間}

昭和 62 年 12 月 11 日 16 日の放課後, 1 人の調查 時間は15分〜25分間程度であった。

\section{III. 結果とその考察}

\section{1)形段階について}

それぞれの段階については，記録用紙を見てか ら決定した。各段階について $2 \sim 3$ 事例を若干の コメントを付けて，すべての答えを示したい。な お，ク以下についても付記したい。 $<>$ 教師

(1) ア〜キについて

ア 不明 無言の場合, 補助的質問をしてもわ からない。様々な具体的な質問を続け「マンショ ンの屋上，明るいものが見える，木，家」（2 年 C)

イ 断片的指摘「屋根に雪がいっぱいある。
向らの方に木がある。草の上にも雪がある。学校 がある」( 2 年 C), 地図記号に気づき記号の質問 をしたあと「米, 家, 池, 神社が岕る, 駅があ る，水神様がある」(2 年A）「ジャングルだ， 川があってその中に島がある, 家もある」（5 年 C)

ウ 比較して指摘（主として量的に）「八干代 台のラオックスが光って見觉る。森，家もたくさ んある。電線と電柱が何本も立っている。第二小 学校, マンションがある。中が低くて左右が高 い」（3 年 B）「田が一面に広がっている。家が ちょこちょこある」（4年B）「外国の川で黄河 かナイル川一水が污れているから，木が多くほと んど家が見えない，ジャングルだ」（5 年 C)

工位置関係で指摘「真中に小学校, その向 うにラオックスというお店, 左にゴルフ場, 下に ソレイユマンション, ところどころに電線, <家 の建ち方と土地の高さについて気づかなか〉家 があって住宅地だ，ソイユは低地であとは台地に 建っている」（5年B）「東金市だ，中心に烟と か田がある。左の方は木とか桑畑がある。<茶色 の線が目立つところはどんなところか>茶色は高 いところ」（3 年B）「ソレイユマンションがあ って和家の買えない人が住む, そして, 左手の木 のあたりは森, 前の方はいろいろな招家, 学校の 右も森，その前にあるのは技家，＜土地の高いと ころと低いところがわかるか>右の方が土地が高 い，左の方も高い，手前は低い，第二小のあたり も低い」( 2 年A)

オ 比較と位置関係の両者によって指摘「森 
の中に川が 2 本ある，家が少しあって小さな島が ある，川がきたない，まわりは緑だらけ，木は混 んでいる，ジャングルだ」（4 年B）「田が多い， 畑も多い，ところどころに寺や神社が見觉る，町 の中心は家が多い, 住宅地が多い，〈これは何か> 両総用水，〈何か知らないか>下総と上総にまた がっている用水，水の足りない田だったから引い た」( 5 年 C)

カ 全体を概観「住宅地で家が広がっている。 マンションの向うに森があって第二小がある。西 の方はゴルフ場がある。手前の道が 1 番通り，だ んだん $2 ， 3$ 番となっている。この辺には家が多 く，買物だと八千代台に行く。ポポやエルムがあ るから，北の方は森が多くて下に川がある（3 年 B）「正面に学校があって電線がたくさん目につ く。木が広がりその前に家が多い。土地は両側が 高く真中が低い。全体に住宅地になっている。第 二小むたりが低い」（6年C）「川の真中に島が ある。林の中に家が少しある。右側の川と水の色 が違う。医とんぞが森で木は混んでいる」（4年 C)

キ 全体を説明的に「だいぶ新しい家が建っ ている。砂利道がありマンションがある。空地は 少ない。第二小より遠くに森, 竹やぶもある。全 体に家がぎっしりあって住宅地。道が碁盤目のよ らに見える。土地はマンションのあたりが低く左 右の家は高い」（6年A）「にごった川が 2 本あ る。林か森になっていて家がはなればなれに少し 建っている。森は遠くまで広がっている。川は曲 っていて中に島がある。木はぎっしりつまってい る。ジャングルだ。くどうしてジャングルになる のか>気候がよい，木が育つ栄養がある，温度が 高い, 雨が多い」(4年A)「ここは東金市で盆地 という感じか扇状地のようで田が広がっている。 高い力は針葉樹で松，杉などがあるのだろう。畑 も高い方にある。畑も多いが荒地も多く沼や池も ある。鉄道があり道路があり集落もある。ゴルフ 場もあるからそれ程高くはない。50～60mくらい だ。神社や寺も多く学校もある。区画整理され用 水飞整っている。郵便もある。<用水路があるが どらしてか>池が多いから池から水を引いてい る。もともと水が手に入りにくい田だったので両 総用水を引いた」（6 年A）
(2) ク〜サについて

屋上からの風景を観察させる際に, 地形をどう 観察するかをみるために、下総台地ととれを刻ん だ八千代東谷がわかるかどらかを調査した。風景 の観察をする中でそれを答えている場合はそれで よしとし，地形に触孔ない場合には，土地の高低 についての質問をして答えさせた。

ク土地の高低がわからない。

ケ一部不明瞭だったり，断片的にわかってい たりする。

コ一続きの谷として把握し、両側の台地と区 別できる。

サ 風景を観察する中で, 前は荒地だったが住 宅地になった。川がはんらんしたが，いまはコン クリートで固定された。川の近くに葛の自生地が あったが，いまはなくなった，など，地域内の変 化に目を付けた者である。中学校の身近な地域の 学習との関連を図る上で参考までにあげた。

熱帯雨林の写真の読みとりの中で聞いてみた。

ク ここはアマゾンだ，といった間違えであっ ても外国の場所を具体的に想像した者。

ケ 熱帯林が出来た気候の特徵がいえる

コ ジャングルという言葉を聞いたことがあ る。

2.5 万分の 1 地形図「東金」の読図の際に，4 年生で学習する両総用水について聞いた。

ク両総用水を引いた背景としての水不足の水 田地帯について気付いた場合である。な和，2〜 3 年生でも用水路に気付いた場合には聞いてみ た。

\section{2）結果についての全体的傾向}

風景の観察力, 写真の読解力, 地形図の読図力 については，それぞれについて学年による発達の 差異が若干認められるが， 2 年生から 6 年生へと 学年がすすむにつれて次のような発達傾向がある といえる。

ア断片的な指摘の段階

見たり読んだりしたことを他の事象との関係を 考觉ずに断片的にいう。この段階は 2 年生に多く みられる。中・高学年でも下位の児童の中にはこ の段階にとどまっている者もいる。断片的な指摘 は, 低学年の特徵であるとい方よう。 
表 2 屋上か ら の 観察

\begin{tabular}{|c|c|c|c|c|c|c|c|c|c|c|c|c|c|c|c|}
\hline (1) 屋上からの観察 & 2 & & 年 & 3 & & 年 & 4 & & 年 & 5 & & 年 & 6 & & 年 \\
\hline 段階 & $\mathrm{C}$ & B & $\mathrm{A}$ & $\mathrm{C}$ & $\mathrm{B}$ & A & $\mathrm{C}$ & $\mathrm{B}$ & $\mathrm{A}$ & $\mathrm{C}$ & $\mathrm{B}$ & $\mathrm{A}$ & $\mathrm{C}$ & $\mathrm{B}$ & A \\
\hline ア 不明 & $\cdot$ & $\cdot$ & & & & & & & & & & & & & \\
\hline イ 断片的指摘 & $\dot{ }$ & • & $:$ & $\dot{.}$ & & & & & & $\cdot$ & & & & & \\
\hline ウ 比較して（量的） & & : & & • & $\cdot$ & $\cdot$ & $\dot{0}$ & - & & & & & & & \\
\hline 工位 置 関 係 & & & $\cdot$ & $\cdot$ & & $\dot{5}$ & $\cdot$ & • & $\cdot$ & & $\cdot$ & & & & \\
\hline オウナェで指摘 & & & & & $\dot{.}$ & $\cdot$ & $\cdot$ & $\cdot$ & $\dot{0}$ & & $\cdot$ & $\dot{0}$ & $\cdot$ & & \\
\hline カ 全 体を概 観 & & & & & $\cdot$ & & & • & - & : & : & & & : & \\
\hline キ 全体を説明 & & & & & & & & & & & & : & $\cdot$ & • & $\because$ \\
\hline ク 土地の高低つかめ & • & • & & & & & & & & & & & & & \\
\hline ケい"あいま & $\dot{0}$ & $:$ & $\dot{:}$ & : & $\vdots$ & & . & - & & : & & & & & \\
\hline コきる & & & $\cdot$ & $\cdot$ & • & $\therefore$ & $\dot{0}$ & $\dot{.}$ & $\because$ & $\dot{.}$ & $\because$ & $\therefore$ & $\because$ & $\because$ & $\because$ \\
\hline サ 地域変化 子指摘 & & & & & & & & & & & & $\cdot$ & $\cdot$ & & $\cdot$ \\
\hline
\end{tabular}

\section{表 3 熱帯雨林の写真（マレーシア）}

\begin{tabular}{|c|c|c|c|c|c|c|c|c|c|c|c|c|c|c|c|}
\hline 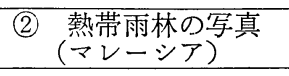 & 2 & & 年 & 3 & & 年 & 4 & & 年 & 5 & & 年 & 6 & & 年 \\
\hline 段階 & $\mathrm{C}$ & $\mathrm{B}$ & A & C & B & A & $\mathrm{C}$ & $\mathrm{B}$ & A & C. & $\mathrm{B}$ & $\mathrm{A}$ & C & $\mathrm{B}$ & A \\
\hline ア 不明 & & & & & & & & & & & & & & & \\
\hline イ 断片的指 摘 & $\dot{.}$ & $\cdot$ & & & & & & & & $\cdot$ & & & & & \\
\hline ウ 比較して（量的） & $\dot{0}$ & $\dot{.}$ & $\dot{0}$ & $\dot{.}$ & - & & : & $\dot{.}$ & & • & & & & & \\
\hline 工 位 置 関 係 & & & & & & & & & & & & & & & \\
\hline 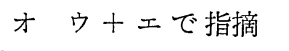 & & $\cdot$ & $\cdot$ & $\dot{.}$ & $\dot{0}$ & & $\cdot$ & • & & - & & & $\cdot$ & $\cdot$ & \\
\hline カ 全 体を概 観 & & & & & - & $\because$ & - & $\cdot$ & & - & : & & $\dot{\cdot}$ & $\cdot$ & \\
\hline キ全体を説明 & & & & & & & & & $\because$ & & $\cdot$ & $\because$ & - & $\dot{.}$ & $\because$ \\
\hline ク 場所を想像する & & $\cdot$ & & & $\cdot$ & & & $\cdot$ & & - & & $\dot{.}$ & $\dot{0}$ & $\dot{0}$ & $\dot{0}$ \\
\hline ヶ＼cjkstart高温多雨（原因） & & & • & & & - & $\cdot$ & $\cdot$ & $\dot{0}$ & & & $\cdot$ & $\dot{.}$ & $\dot{.}$ & $\dot{0}$ \\
\hline コ ジャングルの語 & $\cdot$ & & : & $\dot{0}$ & $\because$ & $\therefore$ & $\because$ & $\because$ & $\therefore$ & $\therefore$ & $\because$ & $\therefore$ & $\therefore$ & $\dot{:}$ & \\
\hline サ & & & & & & & & & & & & & & & \\
\hline
\end{tabular}


表 42.5 万分の 1 地形図「東金」

\begin{tabular}{|c|c|c|c|c|c|c|c|c|c|c|c|c|c|c|c|}
\hline $\begin{array}{l}\text { (3) } 2.5 \text { 万分の } 1 \text { 地形 } \\
\text { 図(東金) }\end{array}$ & 2 & & 年 & 3 & & 年 & 4 & & 年 & 5 & & 年 & 6 & & 年 \\
\hline 階 & C & B & A & C & B & A & C & B & A & $\mathrm{C}$ & B & A & $\mathrm{C}$ & $\mathrm{B}$ & A \\
\hline ア 不 … 明 & : & : & & & & & & & & & & & & & \\
\hline イ 断片的指摘 & • & - & • & $\cdot$ & $\cdot$ & & • & & & - & & & & & \\
\hline ウ 比較して（量的） & & & • & • & $\cdot$ & & $\cdot$ & - & & & & & & & \\
\hline 工 位 置 関 係 & & & & . & - & & & & & & & & & & \\
\hline オ ウ + エで指摘 & & & & & & • & & - & & . & . & & & & \\
\hline カ 全体を概観 & & & & & $\cdot$ & $\dot{0}$ & $\dot{.}$ & : & $\because$ & $\cdot$ & $\dot{0}$ & • & • & & \\
\hline キ 全体を説明 & & & & & & & & & & & & $:$ & : & $\therefore$ & $\because$ \\
\hline $\begin{array}{c}\text { ク両総用水, ため池 } \\
\text { の説明 }\end{array}$ & & & . & & & & • & 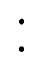 & - & & & $\dot{:}$ & : & $\because$ & $\therefore$ \\
\hline ケ & & & & & & & & & & & & & & & \\
\hline ב & & & & & & & & & & & & & & & \\
\hline サ & & & & & & & & & & & & & & & \\
\hline
\end{tabular}

1 比較・位置関係で指摘の段階

事象を見て広狭，多少，隣接などの意識が働く 段階である。低学年でも若干みられるが，中学年 飞和いて最も発達する。比較と位置関係は，どち らが難しい見方なのかはこの調査からはい党な い。しかし，両者の見方を併せて観察したり，読 みとったりする者といずれか一方で観察したり， 読みとったりする者がある。両者を併せていえる ようになる方が発達上高いのは当然で, これは, 中学年で注涪発達すると思われる。

\section{ウ 全体を概観する段階}

何らかの形で全体を見て特色を指摘できる段階 である。 3 年生でも上位の児童はかなり出来るよ らになるが，風景の観察では 5 年生にならないと 難しいという結果が出た。写真は，全体が見やす く, 地形図は記号がわかってくれば全体を把握し やすいのであるう。風景を全体として概観するに は，高学年にならないと難しい。それは，広さを まとめる力，すなわち，広い視野で事象を見て特
色を把握する力は高学年にならないとつきにくい ためといえよう。

工 全体を説明的に把握する段階

写真の読みとりでは 4 年生の上位から出来るよ らになるが，地形図の読図や風景の観察では 5 年 生の上位，さらに，6年生で安定した力になる。 事象を関係づけて説明する力は，資料によって差 異があるが， 4 〜年生頃からの指導が重要な鍵 を握っていると思われる。そして，6 年生でも関 係づける力は多くの事象までは難しく, 中学校に 引き継いで伸長する。

断片的一比較・位置関係一全体を概観一全体を 説明的といら発達傾向が調査によってわかったが カーブは直線的ではない。地域学習の成果が身に 付く 3 年生のカーブが最も飛躍的で, 次いで, 地 理的学習が一通り終る 6 年生が伸びる時期になっ ている。 $4 \sim 5$ 年生は学力の醸成期であり, 中学 校 1 年生後半からの発展期と続く。 


\section{3）写真，風景，地形図の資料としての意味}

一般的には，見学などによる実物が最も効果的 な資料になる。そうした意味からは風景が最もよ く読みとれる資料になると考光ていた。しかし， 実際には，3つの資料の中では写真が最も読みと りやすい資料とい光た。次いで，風景，地形図と みてよいようである。風景は, 具体的であるが焦 点を定めにくく，単に示せば漠然とした資料でし かなくなることを意味する。駅や商店街を見学す るとか，工場や水田を観察するのと異なり，高い 所から様々な事象を含む風景の場合には，観察眼 を育成するための指導が必要である。高い所から 観察させる 3 年生の地域学習は勿論のこと, 地理 学習では留意しなければならない点である。

地形図については，すでに若干報告したことが あるが ${ }^{14)}$, 等高線が少なく,土地利用が複雑なるの でなければ 3 年生から使用が可能である。地形図 は，記号に慣れ等高線を面倒がらないようにする には, 4 年生の後半ごろから指導するのが適切の ように思う。複雑な地形図は, 小学校高学年でも 抵抗が大きく，中学校でもかなりの指導が必要で あろう。地形図の地理教育への役割は極めて大き い。3 年生では分解して現地や写真と対応し， 4 年生からは，分解を少なくしていく指導手順が必 要になろう。

写真は, 視点が限定される難点があるものの, 焦点化され，まをまりのある形になっている。そ のため, 児童にとってはわかりやすく, 資料とし て効果的なのであろう。大型パネル，スライドな どは画面が大きく児童は喜ぶ。VTRは動きがあ り，連続した形でみられるので児童は強い関心を 示す。教科書や参考書などの写真は，一般に小さ いが効果的であることには変わりがない。授業中 に写真を採り上げて学習をすすめる例は多い。し かし，それに十分時間をかけて読み取らせる授業 には, 岗まり出合わないのは，写真の持つ効果を 生かせないことになる。写真をよく見せ，不明な 点は解説してやれば，例光小さな写真でも読み取 ることは多い。授業計画の中に資料の読み取り時 間をできるだけ多く組み入れるよう再考したい。

\section{4）地形（高低）の判断}

風景から土地の高低を判断出来るようになるの は 3 年生の上位児童からであるが，全体的にみれ ば 4 年生の頃からほ湆判断出来るようになる。ま た，地形図から等高線（本調查では台地）を見つ けて高低を判断出来るのも風景の視察の場合とほ ぼ同傾向にある。しかし，4 年生で等高線を判断 させるには，面接に持ける質問から考えてるかな りの指導が必要である。授業に拈いて常用してる 大きな抵抗がなくなるのは, 複雑でない図の場合 で 5 年生からであろら。地形を判断させる場合, ぞうしてる現地と地形図の対比が必要である。坂 道を歩かせ, 傾斜を体験, 観察させることであ る。この学習は, 中学年が鍵を握っていると思 う。また, 直接体験や観察が難しくなる 4 年生後 半から 5 年生では, 模型（垂直率が高すぎるのが 多い）や断面図，写真などを併用して効果をあげ たい。小学校の中・高学年での深め方をおさえて 扣くことが肝要である ${ }^{15)}$ 。地形のみでなく地図を 利用しての学習は, 小・中学校間に断層があって 困難ではあるが，この現状を何としても解決しな くてはならない。

\section{5）関係づけるカ}

調査を実施する中で，写真の読解のときに，ジ ヤングルと高湿多雨の気候との関係, 地形図の読 図のときに，水田と用水の関係を聞いてみた。こ の 2 例から関係づける力について考察したい。結 論的には，いずれの場合も 6 年生にならないと難 しいといえる。写真では,「ジャングル」の語に ついては低学年でも上位の児童は知って和り， 中・高学年になれば活とんどの児童が知ってい る。しかも，写真を見てとれと判断することが出 来る。しかし，それが熱帯にみられ，具体的にど のような気候なのかを問らとあいまいになる。言 語的な表面的理解ということになる。小学校段階 では，理由の前に事実についての精しい理解があ ればよいのであろう。地形図の場合，用水と稲作 の関係について, 稲にとって水が必要であること の理解，九十九里平野がかつて天水田でしばしば 旱害に悩まされていたことの理解などが前提とし

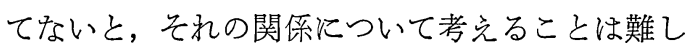
い。ジャングルの場合と同様に，事実に関する学 習を十分に行うのが小学校の役割であろう。 
小学校高学年に秥いて，関係づけて考学る力が 伸びてくるが，事実の十分な理解なくしては非論 理的な想像の段階の思考になってしまう。中学校 に特いて短絡的思考を是正し，事実に基づいた論 理的思考を発達させようとする場合, 小学校高学 年に拈ける指導が，重要な役割を果たすことにな る。

\section{IV．まとめと指導上の留意点}

風景の観察, 写真, 地形図からの読みとりの能 力の発達傾向をみると, 学年が進行するにつれ $\tau$, 断片的指摘 $\rightarrow$ 比較 - 位置関係から指摘 $\rightarrow$ 全体 を概観 一全体を説明的に把握となる。その中で， 先ず第 3 学年, 次いで第 6 学年に飛躍期が認めら

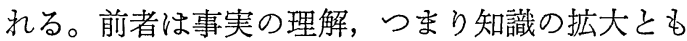
とれ，後者では関係づけの初歩的思考が発達す る。3つの資料の中では，写真が最も児童にわか りやすいといえる。

現在，小学校の社会科学習に和いて，問題解決 型の授業過程が支配的に根付いている。それにつ いてのコメントは省略するが，この授業過程の中 に調べ学習が位置づけられている場合が多い。児 童は学習活動として各自で，あるいはグループで 教科書をはじめ地図帳，諸資料を利用して調べて いく。この際, 写真や地図をじっくりと観察し, そこからわかることを読み取るといらより，直観 的に気付いたことをメモしたり，それぞれの解説 文に頼ったりする傾向がみられる。そして，わか ったような感じですすんでしまう。これでは，こ れらの資料のもつ価值も損われ，読み取り能力の 進歩も難しい。資料の読久取り方の指導, 訓練に 十分な時間をかけたい。な和，その際，児童の年 齢に応じた発達段階を配慮した要求水準を設定し なければならないことはいうまでもない。

この拙論は，昭和63年 8 月に香川大学で開催さ れた日本地理教育学会で報告したものに加筆した ものである。ご指導，ご叱正を贈れば幸甚であ る。

\section{謝 辞}

調查にあたり，千葉市立柏井小学校の第 2 学年 ～第 6 学年 (昭和 62 年度) の各担任の方々にご協
力をいただいた。また，日置裕一教諭（現千葉市 立蘇我小), 柳沢修樹教諭（現柏井小）, 高橋知夫教 諭（現千葉市立犢橋小）の 3 名には，面接の協力 をいただいた。深く感謝の意を表したい。

\section{（注）}

1）文部省(1960)：「小学校社会科指導書」二葉株式 会社

2）文部省(1969)：「小学校指導書社会編」大阪書籍

3）文部省 (1978)：「小学校指導書社会編」大阪書籍

4）文部省(1980)：「小学校社会指導資料・指導計画 の作成と学習指導」ぎょうせい

5）椙村大彬，佐島群己，三木薰子，須田担男，中村 治行, 菅野浩, 河崎省吾 (1964)：「社会科学習に打 ける子供の観察態容とその学年的発達段階の特色に 関する研究」その 1 , その 2 , 新地理 $11-4,12-$ 1 ,

6）岩本広美, 安藤正紀, 寺本潔, 吉田和義, 松井美 佐子(1985): 子ぞもの心理的発達に関ずる地理学的

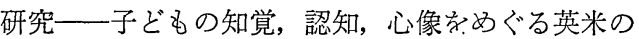
研究動向を中心にして——新地理33-2

7）寺本 潔(1985)：子ぞもの知覚環境と社会科学習 地理30-- 1 古今書院

8）山口幸男, 黒崎至高(1988): 児童生徒に特ける距 離, 位置, 面積の認知, 理解に関する地理教育的研 究の概要 群馬大学教育実践研究 5 号

9）R. ヘート（岩本広美抄訳1984）：風景に対する子 ぞもの空間表象——野外研究からの教訓と課題— 新地理 $32-3$

10）寺本 潔(1988)：『子ども世界の地困』 黎明書房

11）鳥海 公(1965)：中学生の地理的思考や理解の傾 向 その 1 , その 2 新地理 $13-2,3$

12）鳥海 公, 粒良進午, 滝口昭二(1971)：身近な地 域学習と大縮尺地図指導の位置づけ 新地理18-4

13）䠌沢文隆(1984）：地理教材としての写真資料 筑 波大学附属中学研究紀要36号

14）鳥海 公 (1987)：小・中学校一貫の地理教育校中学年の地域学習と中学校諸地域学習を中心に 小学——新地理 $34-4$

15) 14) 子.同じ

$$
\text { (とりらみここ＝千葉市立あやめ台小学校長 })
$$

